\title{
Analysis of complications after surgery for colorectal cancer with particular consideration to anastomotic leakage
}

\section{Analiza powikłań u pacjentów operowanych z powodu raka odbytnicy ze szczególnym uwzględnieniem nieszczelności zespoleń}

\author{
Monika Kozłowska1 , Stanisław Głuszek² \\ ${ }^{1}$ Clinic of General Oncological and Endocrinological Surgery, Regional Hospital, Kielce, Poland \\ Head of the Department: Prof. Stanisław Głuszek MD, PhD \\ 2Department of Surgery and Surgical Nursing with Research Laboratory, Faculty of Health Sciences, Jan Kochanowski University, \\ Kielce, Poland \\ Head of the Department: Prof. Stanisław Głuszek MD, PhD
}

Key words: colorectal cancer, anastomotic leakage, complications after surgery.

Słowa kluczowe: rak odbytnicy, nieszczelność zespolenia, powikłania pooperacyjne.

\begin{abstract}
Introduction: Anastomotic leakage is among the most common and most serious complications after colorectal surgery. It may lead to the necessity of repeating the procedure, prolongation of hospitalisation period, and an increase in the mortality rate. Aim of the research: The objective of the study was an analysis of complications, with particular consideration paid to colorectal anastomotic leakage, in patients who had undergone surgery due to colorectal cancer at the Regional Polyclinic Hospital in Kielce, during 2005-2011.

Material and methods: Into the study group were enrolled 102 patients with colorectal cancer, who had undergone surgery in the Clinical Ward for General, Oncologic, and Endocrine Surgery, at the Regional Polyclinic Hospital in Kielce.

Results: The most frequent complication related to the surgery was superficial surgical site infection, which occurred in 9 patients, i.e. $8.8 \%$. Anastomotic leakage was observed in 3 patients per 46 surgeries with construction of colorectal anastomosis, i.e. $6.5 \%$, colostomy complications were noted in 3 patients per 56 procedures with formation of a colostomy, i.e. $5.4 \%$. Conclusions: Anastomotic leakage is a serious complication after colorectal surgery.
\end{abstract}

\section{Streszczenie}

Wprowadzenie: Nieszczelność zespolenia jest jednym z najczęstszych i najpoważniejszych powikłań po operacjach kolorektalnych. Może prowadzić do ponownej operacji, wydłużenia czasu hospitalizacji oraz zwiększenia śmiertelności.

Cel pracy: Analiza powikłań u pacjentów operowanych z powodu raka odbytnicy na Oddziale Klinicznym Chirurgii Ogólnej, Onkologicznej i Endokrynologicznej Wojewódzkiego Szpitala Zespolonego (WSZ) w Kielcach w latach 2005-2011 ze szczególnym uwzględnieniem nieszczelności zespoleń jelita grubego.

Materiał i metody: Do grupy badanej włączono 102 chorych na raka odbytnicy operowanych w Klinice Chirurgii Ogólnej, Onkologicznej i Endokrynologicznej WSZ w Kielcach.

Wyniki: Najczęstszym powikłaniem związanym z operacją było powierzchowne zakażenie miejsca operowanego, które wystapiło u 9 (8,8\%) pacjentów. Nieszczelność zespolenia stwierdzono u 3 pacjentów na 46 operacji przeprowadzonych z zespoleniem jelita, tj. 6,5\%, powikłania kolostomii dotyczyły 3 pacjentów na 56 zabiegów z wyłonieniem sztucznego odbytu, tj. 5,4\%. Wnioski: Przetoki przewodu pokarmowego jako ciężkie powikłanie nadal stanowią trudny problem chirurgiczny.

\section{Introduction}

Anastomotic leakage is one of the most frequent and most serious complications after colorectal surgery. It may lead to the necessity of repeating the procedure, prolongation of the period of hospitalisation, and an increase in the mortality rate [1]. Anastomosis is most often defined as deviations in clinical or radiological examinations or proctoscopy, which indicate the leak of luminal contents of the intestine from the site of surgical anastomosis [2].
According to the characteristics, three types of anastomotic leakage are distinguished: A, B, and C [3]:

A - Asymptomatic leakage or leakage detected in radiological examination, the presence of which is discovered only in the case of performing routine imaging examinations after the surgery. Its presence does not require any additional therapeutic intervention.

B - Leakage with slight intensity of clinical symptoms. It does not require surgical treatment; the im- 
plementation of conservative treatment is sufficient - antibiotic therapy, drainage, or infusions.

C - Full-blown leakage requiring relaparotomy and the creation of a protective or end stoma.

Another classification has been proposed by Caulfield et al., which is based on the occurrence of deviations in clinical and radiological examinations, and radiological symptoms of leakage.

Class I - free liquid in the pelvis or in the presacral region in the computed tomography (CT) scan, the lack of contrast media extravasation and the presence of abscesses.

Class II - post-surgical abscess, lack of contrast media extravasation in CT scan: a) with an abscess in the anastomosis site, b) with an intra-abdominal abscess located at a distance from the anastomosis.

Class III - restricted contrast extravasation in the presacral region in the CT scan.

Class IV - diffused contrast media extravasation in the CT scan.

In addition, a leakage division may be encountered according to the time of its occurrence. An early leakage is defined as a group of symptoms which occur 8 days after the surgery, on average, while late leakage is that which appears 22 days after surgery, i.e. most frequently after the discharge of a patient from hospital [3].

\section{Aim of the research}

The objective of the study was analysis of complications, with particular consideration of colorectal anastomotic leakage, in patients who had undergone surgery due to colorectal cancer in the Clinical Ward for General, Oncologic, and Endocrine Surgery at the Regional Polyclinic Hospital in Kielce, during 20052011.

\section{Material and methods}

The study group covered 102 patients with colorectal cancer, who had undergone surgery in the Clinical Ward for General, Oncologic, and Endocrine Surgery at the Regional Polyclinic Hospital in Kielce. The study was of a retrospective character.

Criteria of enrolment of patients into the study group: 1) patients who had undergone surgery due to colorectal cancer in a planned mode; 2) female and male patients qualified for surgical treatment during 2005-2011; 3) patients in whom cancer metastasis was excluded; 4) patients without other gastrointestinal cancers; 5) patients qualified on assumption for surgical procedure with an intent to cure; 6) patients with stabilised parameters of additional burdens (internal cardiologic, pulmonological).

Criteria of exclusion of patients from the study group: 1) patients who had undergone surgery in an emergency mode; 2) age under 41 and over 87 years; 3) patients with diffused cancer; 4) patients with more than one gastrointestinal cancer; 5) patients qualified on assumption for palliative surgery, 6) patients considerably burdened with additional diseases (internal, cardiologic, pulmonological).

Subsequently, based on the surgical protocol, the course of surgical procedure was analysed considering the following: surgical access (laparotomy or laparoscopy); site of tumour; surgical method (anterior resection of the rectum by the Dixon's method, lower anterior resection of the rectum - LAR, abdominoperineal resection of the rectum by the Mile's method - APR, resection of the tumour with the creation of an artificial anus by the Hartmann's method, resection of the upper part of the rectum with tumour with endto-end anastomosis); duration of surgery (in minutes); intra-surgical complications (bleeding, perfusion of the tumour, damage to the urethra); experience of the operating surgeon (measured by the number of similar surgeries performed); radicality of the surgery in the surgeon's opinion (R0, R1, R2).

In the postoperative course the occurrence of the following complications was analyzed: general (i.e. respiratory disorders, fever $>38^{\circ} \mathrm{C}$, cardiologic, renal, deep vein thrombosis, pneumonia, pulmonary embolism, sepsis, gastrointestinal obstruction, multiple organ dysfunction); surgical-related with the surgical procedure performed: complications of anastomosis (anastomotic leakage resulting in peritonitis); complications of the stoma (i.e. bleeding from the stoma); surgical site infection (SSI).

\section{Statistical analysis}

Statistical calculations were performed by statistical techniques that are a set of selected procedures for survival analysis. The methods applied enable the consideration of so-called cut-off observations, for which the survival time is incomplete. The collected data were statistically analysed using the log-rank test. Visualisation of statistical data was performed using column charts, pie graphs, box plots, and histograms. In the box plot, illustrating the distribution of quantitative statistical characteristics, the following were presented: median, quartiles, and extreme values. The $p$ values $<0.05$ were considered statistically significant.

The literature was collected based on the Medline database. The articles were checked from the aspect of their relation to the examined problem. Prospective, random, controlled trials, meta-analyses, and retrospective evaluations of randomly controlled studies in the collected reports were preferred as a reference to the results of our own studies.

\section{Results}

With the application of inclusion and exclusion criteria (discussed in the section Material and methods), 102 patients were qualified for the study, aged 
Table 1. Classification of patients according to the stage of clinical advancement of cancer TNM

\begin{tabular}{|lcc|}
\hline TNM classification & Total & Total (\%) \\
1 & 5 & 4.09 \\
2 & 11 & 10.8 \\
3 & 74 & 72.5 \\
4 & 12 & 11.8 \\
\hline
\end{tabular}

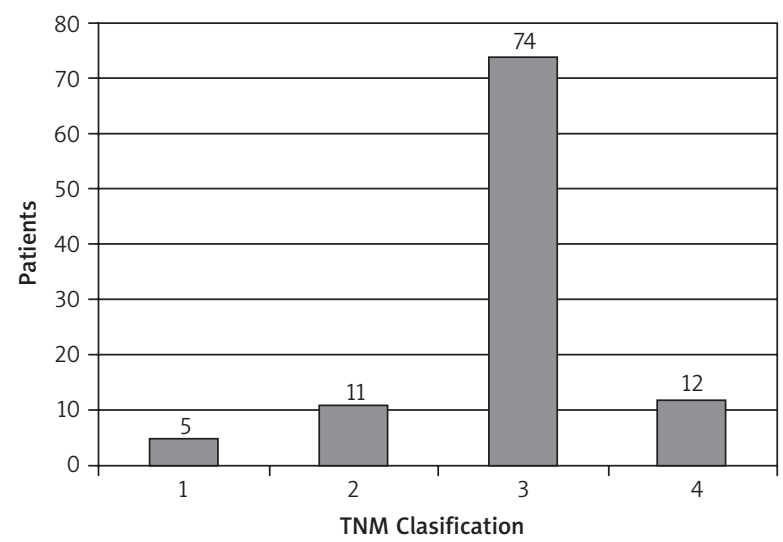

Figure 1. Distribution of the number of patients with degree 1, 2, 3, and 4 determined based on the stage of clinical advancement of cancer TNM

41-87 years, including 41 females and 61 males, with colorectal cancer grade I-IV confirmed by histological examination, who had undergone surgery in a planned mode during 2005-2011. These were patients with a single gastrointestinal cancer confirmed by preoperative examinations, without the diagnosis of cancer metastasis, with stabilised parameters of additional diseases (internal, cardiologic, pulmono-

Table 2. Classification of patients according to the stage of clinical advancement of cancer UICC

\begin{tabular}{|lcc|}
\hline $\begin{array}{l}\text { Stage of advancement } \\
\text { of cancerous disease } \\
\text { UICC }\end{array}$ & Total & Total (\%) \\
I & 16 & 15.7 \\
IIA & 30 & 29.4 \\
IIB & 0 & 0 \\
IIC & 0 & 0 \\
IIIA & 1 & 1 \\
IIIB & 29 & 28.4 \\
IIIC & 15 & 14.7 \\
IVA & 11 & 10.8 \\
IVB & 0 & 0 \\
Total & 102 & 100 \\
\hline
\end{tabular}

logical), who were qualified on assumption for radical surgery with an intent to cure.

Table 1 and Figure 1 show that definitely the largest group were patients who had undergone surgery at stage 3 of clinical advancement of cancer (TNM 3) - 74 patients, i.e. $72.5 \%$. Only 5 patients operated on were in the initial stage of clinical advancement of cancer (TNM 1).

Among the patients who had undergone surgical procedure the largest group were those with the stage of clinical advancement of cancerous disease UICC IIA (29.4\%) and IIIB (28.4\%). Stages IIB, IIC, and IVB were not ascribed to any of the patients (Table 2).

In $52(51 \%)$ patients the tumour was localised in the upper part of the rectum, i.e. above the peritoneal pouch, in 50 (49\%) patients the tumour was located in the lower part of the rectum - so-called anal, i.e. below the pelvic diaphragm.

Figure 2 demonstrates that the probability of survival for a specified time by patients with cancer located in the lower rectum is higher than in the group of patients with cancer present in the upper rectum. The log-rank test allows the consideration of these differences as statistically significant ( $p=0.0017)$.

In $99(97 \%)$ patients surgical access to the tumour was obtained using laparotomy, while in 3 (3\%) patients - by laparoscopy.

Table 3 shows that anterior resection of the rectum by Dixon's method was the most frequently performed surgical procedure, and was performed in every second patient. The mean time of surgery was $156 \mathrm{~min}$.

The most frequent intra-surgical complication was iatrogenic perforation of the tumour, in 6 patients, i.e. $5.9 \%$ (Table 4).

Table 5 and Figure 3 show that the most common systemic postoperative complication was fever over $38^{\circ} \mathrm{C}$, persisting for more than 2 days. This complica-

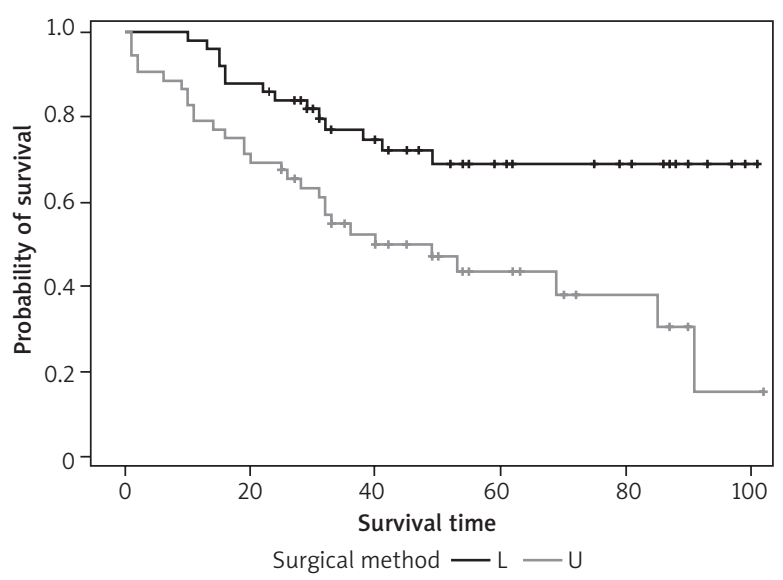

Figure 2. Survival curves, expressed in months, for patients with location of cancer in the upper $(U)$ and lower (L) rectum 
Table 3. Type of surgery performed in the group of patients in the study

\begin{tabular}{|lcc|}
\hline Type of surgery & Total & Total (\%) \\
$\begin{array}{l}\text { Anterior resection of the } \\
\text { rectum by Dixon's method }\end{array}$ & 44 & 44.9 \\
$\begin{array}{l}\text { Abdominoperineal resection } \\
\text { of the rectum by Mile's } \\
\text { method (APR) }\end{array}$ & 18 & 17.6 \\
$\begin{array}{l}\text { Resection of the tumour with } \\
\text { the creation of an artificial } \\
\text { anus by Hartmann's method } \\
\text { Lower anterior resection } \\
\text { of the rectum (LAR) }\end{array}$ & 34 & 33.3 \\
\hline
\end{tabular}

Table 5. Systemic postoperative complications

\begin{tabular}{|lcc|}
\hline $\begin{array}{l}\text { Systemic postoperative } \\
\text { complications }\end{array}$ & Total & Total (\%) \\
Fever $>38^{\circ} \mathrm{C}>2$ days & 8 & 7.8 \\
$\begin{array}{l}\text { Bleeding from upper part } \\
\text { of gastrointestinal tract }\end{array}$ & 4 & 3.9 \\
$\begin{array}{l}\text { Multiple organ failure with } \\
\text { hospitalisation in ICU }\end{array}$ & 4 & 3.9 \\
$\begin{array}{l}\text { Dyspnoea } \\
\text { Urinary tract infection }\end{array}$ & 4 & 3.9 \\
$\begin{array}{l}\text { Renal failure } \\
\text { Pneumonia }\end{array}$ & 3 & 2.9 \\
$\begin{array}{l}\text { Aggravation of cardiovascular } \\
\text { failure }\end{array}$ & 2 & 2.9 \\
Respiratory failure & 2 & 2 \\
\hline
\end{tabular}

Table 4. Intra-surgical complications

\begin{tabular}{|lcc|}
\hline Intra-surgical complications & Total & Total (\%) \\
latrogenic perforation of tumour & 6 & 5.9 \\
Complications of anastomosis & 3 & 2.9 \\
Damage to intestine & 3 & 2.9 \\
Damage to urethra & 1 & 1 \\
\hline
\end{tabular}

tion occurred in 8 patients, i.e. 7.8\%. Four (3.9\%) patients with postoperative multiple organ failure, concerning cardiovascular, respiratory, and renal failure were hospitalised in the Intensive Care Unit.

The most frequent complication related with the surgery was superficial surgical site infection, which was observed in 9 patients, i.e. $8.8 \%$. Anastomotic leakage was noted in 3 patients per 46 surgical procedures with intestinal anastomosis, i.e. 6.5\%; colostomy complications concerned 3 patients per 56 surgeries with creation of an artificial anus, i.e. $5.4 \%$. The patients were hospitalised in the surgical ward for 6 days, on average. All patients, i.e. 102, survived the surgery, early and late postoperative period, and were discharged from the Surgical Ward in a generally good state (Table 6).

\section{Discussion}

Colorectal cancer is a serious challenge for oncology in the $21^{\text {st }}$ century. The majority of patients are aged about 70 years. Annually 875,000 new cases of colorectal cancer are registered worldwide, and the global mortality is 570,000 . This type of cancer constituters $11 \%$ of malicious cancers diagnosed. Colorectal carcinomas constitute $5.4 \%$ of cases in males and

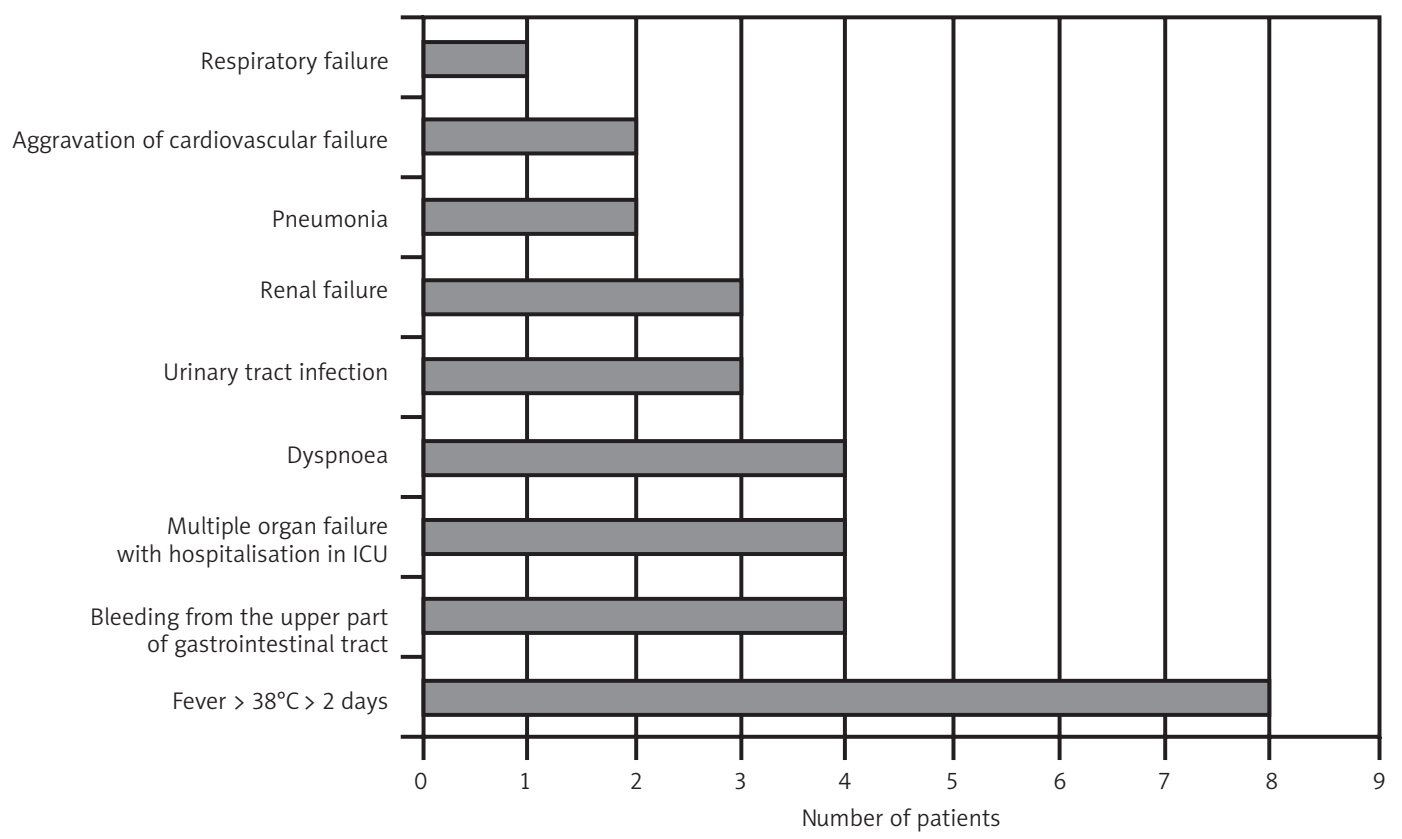

Figure 3. Distribution of the number of patients in the group examined according to systemic postoperative complications 
Table 6. Specific postoperative complications

\begin{tabular}{|lcc|}
\hline $\begin{array}{l}\text { Specific postoperative } \\
\text { complications }\end{array}$ & Total & Total (\%) \\
Superficial surgical site infection & 9 & 8.8 \\
Anastomotic leakage & 3 & 6.5 \\
Colostomy complications & 3 & 5.4 \\
\hline
\end{tabular}

$3.8 \%$ of cases in females [4]. In 2010, the number of cases of malicious colorectal cancer was 6,448 , including almost 3,800 cases among males, and more than 2,600 in females.

Surgical procedure still remains the leading and basic method of radical treatment of colon and rectal cancer, and the experience and care of the operating surgeon exert an important effect on the prognosis. On this depend both the number of post-operative deaths and seriousness of complications, as well as distant outcomes. This is confirmed by the excellent percentages of survivals obtained in specialised centres. These outcomes are decisively better than in facilities without a special interest in colorectal cancer. Statistically significant differences between the results of treatment in individual hospitals remain after the exclusion of other potential causes of worse prognosis. Borie et al. [5], using multi-variant analysis, demonstrated that the onset of treatment of colon and rectal cancer in a non-specialised centre is an independent factor that in a significant way deteriorates total survivals.

Clear differences are also observed between individual surgeons [6]. Phillips et al. [7], based on the study material of several thousand patients, noted a statistically significant difference in locoregional recurrence rates between surgeons, from below 5\% to over $20 \%$. This difference remained significant also after stratification according to the stage of advancement and the operating surgeon, and proved to be an independent prognostic factor. The importance of the quality of surgical treatment was later confirmed on many occasions. In the already classic publication by McArdle and Hole [8] the differences in cancer resectability were $40-76 \%$ (mean $52 \%$ ), in postoperative mortality $-8-30 \%(16 \%)$, anastomotic leakage $-2-22 \%(8 \%)$, infection of body integuments $-6-35 \%$ (22\%), and wound separation - 0-11\% (5\%), whereas in intra-abdominal purulent complications it was $0-10 \%(4 \%)$. These differences were significant and independent of the stage of advancement of the disease, patient's age, and indications for emergency surgery. The results of studies by Smith et al. confirmed the importance of the role of the experience of a surgeon, and how difficult and work consuming the acquisition of appropriate skills and thoroughness can be [9]. This study carried out on a large number of patients indicted that a significant reduction in post- operative mortality rates and anastomotic leakage, and a significant improvement in the overall and recurrence-free survival was associated with surgeons performing more than 50 surgeries of colon and rectal cancer annually. Thus, it seems that the quality of surgical treatment has great prognostic value, and its independence on other prognostic factors may be considered as evidenced.

In the study group, the mean duration of surgical procedure was $156 \mathrm{~min}$.

It was confirmed that obstruction is an independent factor that significantly affects the frequency of recurrences and the deterioration of overall and asymptomatic survival. Also, many reports presented a significant negative effect of tumour perforation on the outcomes of treatment. Runkel et al. [10], in a very recent report, demonstrated that both tumour perforation and obstruction are independent factors that increase the risk of death due to rectal cancer to a highly statistically significant degree. These results are confirmed by reports presenting clearly worse results of treatment in cases of unintentional perforation during surgery for non-complicated cancer. Therefore, a poorer prognosis among patients who have undergone surgery in an emergency mode does not evoke controversy. However, considering a strong correlation with the advancement of the tumour, the prognostic value of acute complications of cancer as an independent parameter is a disputable issue.

In the examined group of patients, the most frequent intra-surgical complication was iatrogenic perforation of the tumour, as seen in 6 patients, i.e. 5.9\%, whereas the most common systemic postoperative complication was fever over $38^{\circ} \mathrm{C}$ persisting for more than 2 days, as seen in 8 patients, i.e. $7.8 \%$. Four (3.9\%) patients with postoperative multiple organ failure, including cardiovascular, respiratory, and renal failure, were hospitalised in the Intensive care Unit.

Many previously published reports concerned a statistically worse prognosis in patients with colon cancer, compared to those with rectal cancer. Also, the deterioration of the outcomes of treatment of rectal cancer was presented in association with a lower location of the tumour. More frequent local recurrences were observed in cancers located in the lower and middle part of the rectum, and a shorter time of their development. However, a multi-centre study by Phillips et al. [7], conducted on a large number of patients, did not confirm a correlation between treatment failure and location of cancer. Similarly, in only a few reports, the significance of the location of the cancer in particular parts of the rectum was mentioned as a factor resulting in a reduction in the percentage of distant survivals and an increase in the frequency of recurrences. On the other hand, a considerable number of more recent reports indicate the lack of significance of the location of a primary tumour as an independent prognostic parameter. The possible causes of po- 
tentially worse prognosis in rectal than colon cancer may be perceived in the limited space of the smaller pelvis, and additional difficulty in achieving oncologic radicalism, greater technical difficulties, quicker infiltration of tissues and adjacent organs, as well as the lymph nodes being more frequently affected, and a greater heterogeneity of lymphatic drainage. Nevertheless, the majority of reports suggest the lack of an independent effect of the location of the tumour on distant outcomes [1].

Based on literature analysis, among the most important risk factors is the distance between anastomosis and the pectinate line. In 2011, Polish researchers analyzed 884 patients with rectal cancer, nearly $72 \%$ of whom had undergone sphincter preservation surgery. The distance of the anastomosis $\leq 6 \mathrm{~cm}$ from the anal edge resulted in a significant increase in the percentage of anastomotic leakage. It was found that in the case of this type of anastomoses, protective stoma decreases the risk of leakage from $20.5 \%$ down to $6.3 \%$ [3].

In the examined group of 52 (51\%) patients, the tumour was located in the upper rectum, i.e. above the peritoneal pouch; in $50(49 \%)$ patients the tumour was located in the lower rectum - so-called anal, i.e. below the pelvic diaphragm. The log-rank test showed that the probability of survival of patients with the location of cancer in the low rectum is higher than in the group of patients with the site of cancer in the upper rectum. The log-rank test allows the consideration of these differences as statistically significant $(p=0.0017)$.

Gui and Wang [11] analysed the anastomotic leakage in a group of 653 patients who had undergone low anterior resection of rectal cancer. Among patients subjected to preoperative radiotherapy the percentage of anastomoses was $13.3 \%$ (25/195), while in the group without preoperative radiotherapy it was $4.5 \%$ (20/448). Based on multifactor analysis, it was found that one of the factors for a high risk of leakage in these patients was the distance between the anastomosis and the anal edge (less than $4 \mathrm{~cm}$ ). Simultaneously, the researchers [11] observed that the factors mentioned below do not increase the risk of leakage after anterior resection of rectal cancer: gender, body mass index (BMI), nicotinism, preoperative computed tomography (CT), level of albumin and haemoglobin, size of tumour, intra-operative blood loss, duration of surgery, stage of advancement TNM, and preventive stoma [1].

The frequency of anastomotic leakage differs according to various studies, which is primarily due to the different criteria of inclusion of patients into the study. The meta-analysis by Cong et al. concerns 50 studies covering 24,000 patients; however, it contains 40 reports, more than a half of which pertain to less than 10 patients with anastomotic leakage after low anterior resection [12]. In turn, Tana et al., based on 21 studies with the participation of 11,500 patients, compared the percentage of leakages after low anterior resection of rectal cancer. In both meta-analyses the percentage of leakage was relatively high, approximately $8 \%$, on average; however, in some studies it even reached $26.2 \%$. In the meta-analysis performed by Pata et al. the percentage of clinically manifested leakage was 17\% in 358 patients from four randomised studies, and $9.6 \%$ in 4059 patients from 39 observational studies [13].

In the group of patients in the presented study, the most frequent complication related with surgery was superficial surgical site infection, which was observed in 9 patients, i.e. 8.8\%. Anastomotic leakage was found in 3 patients per 46 surgical procedures with intestinal anastomosis, i.e. $6.5 \%$, colonostomy complications concerned 3 patients per 56 surgeries with the creation of an artificial anus, i.e. 5.4\%. The patients were hospitalised in the Surgical Ward for 6 days, on average. All patients (102) survived the surgery, early and late postoperative period, and were discharged from the Surgical Ward in a generally good state.

Cong et al., in their meta-analysis, determined the frequency of occurrence of leakage type A (clinically asymptomatic) as $2.57 \%$ after low resection, $1.14 \%$ after low anterior resection, and $7.41 \%$ in ultra-low anterior resection of the rectum. For type B leakage, these values were: $2.37 \%, 3.75 \%$, and $5.26 \%$, respectively, whereas for type C leakage $-5.4 \%, 4.7 \%$, and $1.81 \%$ [14]. It seems that the percentage of leakage is the highest in the case of ultra-low anterior resection of the rectum; however, the data from meta-analysis still remain unequivocal.

The percentage of anastomotic leakage ranged according to whether a protective stoma was performed or not in a patient subjected to anterior resection of rectal cancer. In a randomised study by Matthiesen et al. covering 234 patients, the percentage of leakage was assessed as $19.2 \%$ (45 patients per 234 ). In patients with protective stoma, this percentage was $10.3 \%$ (12 per 116) and 28\% (33 per 118), while in patients without stoma (OR (odds ratio) 3.4; 95\% CI: 1.6-6.9; $p<0.001$ ) [15]. The frequency of leakage also varied according to its degree and the surgery during which it developed.

An increased risk of complication in the form of postoperative gastrointestinal fistula should be taken into account in elderly patients burdened with metabolic and cancerous diseases, with a past history of radiation therapy, laparotomies, and with renal failure [1].

In surgical management, drainage of the pelvis was routinely considered, optionally a protective stoma, and safe anastomosis on the level at least $4 \mathrm{~cm}$ from the anal verge [1].

In some studies it is suggested that only the age of patients over 60 years constitutes an independent factor for the development of leakage $(p=0.004)$ - a retrospective analysis of a group of 108 patients [1]. 
The American Society of Colon and Rectal Surgeons (ASCRS) consider as the most important risk factors, assuming correctly performed anastomosis with low anterior resection of the rectum: radiation of the rectum in medical history taking, hypoalbuminaemia, malnutrition, steroid therapy, and immunosuppression.

Factors such as surgery performed under emergency duty procedure, contamination by the intestinal contents, intra-operative loss of blood, and long duration of surgery were of less importance. To the abovementioned factors, Polish experts have added: total mesorectal excision (TME), positive test for the tightness of anastomosis and/or incomplete tissue discs excised by a stapler, duration of surgery over $4 \mathrm{~h}$, important intra-surgical difficulties (e.g. very narrow pelvis, technical difficulties), emaciation $-\mathrm{BMI}<19 \mathrm{~kg} / \mathrm{m}^{2}$, burden of ASA III or IV, and a centre performing less than 20 anterior resections annually/a surgeon performing less than 10 anterior resections annually [15].

Based on international literature, a group of Polish experts selected and analysed the most important risk factors of anastomotic leakage described in the studies concerning the period 2010-2014. The risk factors for which $p<0.05$ were considered as statistically significant: male gender, diabetes, age $>57$, obesity, size of tumour $>5 \mathrm{~cm}$, location of the tumour $>5 \mathrm{~cm}$ from the anal pecten, distance between anastomosis $>3 \mathrm{~cm}$ from the anal edge, blood transfusions, loss of $>200 \mathrm{ml}$ of blood, level of haemoglobin before surgery $<8 \mathrm{~g} / \mathrm{dl}$, level of albumin $<3.5 \mathrm{~g} / \mathrm{l}$, intra-surgical hypopotency, neoadjuvant therapy, vascular diseases, steroid therapy, immunosuppression, cigarette smoking, alcohol, and demographic factors - Europe [3].

A high ligation of the inferior mesenteric artery does not improve the therapeutic results, but may increase the risk of ischaemia after anastomosis or colostomy. Usually, a ligation of the inferior mesenteric artery is performed below the left colic artery. In the case of infiltration of the serous membrane by cancer, removal of the greater omentum is recommended [1, 2]. It is considered that a routine blood transfusion is an unfavourable factor from the aspect of prognosis because in the case of necessity for blood administration during surgery the risk of later occurrence of a local recurrence increases, and the prognosis deteriorates. Blood should be administered either prior to surgery or $72 \mathrm{~h}$ after the surgery $[1,6,16]$. Although the effectiveness of all surgical methods of protection of intestinal anastomosis has not been unquestionably proven, it seems that the creation of protective stoma remains the most justified method. This procedure should be especially taken into consideration in the case of co-existence of additional risk factors of anastomotic leakage, such as: older age of a patient, male gender, low extra peritoneal rectal anastomosis, past history of radiation therapy, lack of correct preparation of the intestine, greater intra-operative bleed- ing, necessity for transfusion of blood products, and burden of serious concomitant diseases [1-3].

The scope of the problem of protective stoma still remains a subject of debate. For many years it has been presumed that protective stoma only decreases the symptoms in patients with leakage. However, this conviction has changed in association with the publication of a meta-analysis by Pata et al., who, in their report, unequivocally demonstrated that protective stoma does not only prevent disadvantageous effects of clinically manifested leakage [13]; it was observed that the introduction of protective stoma considerably decreased the number of repeated surgeries due to leakage performed in an emergency mode, which resulted in a considerable reduction of complications and mortality rate [3].

The most frequent indications for the performance of protective stoma are low anterior recto-sigmoid and anal-sigmoid anastomoses, after low anterior resection of the rectum - mainly due to the adenocarcinoma of the rectum. Other clinical situations requiring the performance of a stoma are: restorative proctocolectomy with a 'J' pouch, rectovaginal fistula, vesicle fistula, or post-radiation stricture in the rectal area after radiotherapy.

According to Polish experts, the most important indications are: positive results of test for anastomosis tightness and/or incomplete stapler rings; low anastomosis - distance $<3 \mathrm{~cm}$ from the anal pecten; emaciation - BMI < $19 \mathrm{~kg} / \mathrm{m}^{2}$; neoadjuvant therapy; immunosuppression; ASA III or IV; serious inter-surgical difficulties (including a very narrow pelvis, technical difficulties) [3].

Protective stoma considerably improves the outcomes of surgical treatment. It decreases the effects of the occurrence of anastomotic leakage, decreases the percentage of leakage and repeated surgeries due to this cause, and shortens the duration of hospitalisation [3].

\section{Conclusions}

Anastomotic leakage is a serious complication after colorectal surgery.

\section{Conflict of interest}

The authors declare no conflict of interst.

\section{References}

1. Głuszek S, Korczak M, Kot M, et al. Przetoki przewodu pokarmowego - problem wciąż aktualny. Pol Przegl Chir 2011; 83: 53-69.

2. Dziki A, Wallner G. Wytyczne diagnostyczno-terapeutyczne w raku jelita grubego. Stowarzyszenie Popierania Rozwoju Proktologii 2007.

3. Szczepkowski M, Banasiewicz T, Krokowicz P, et al. Polski konsensus w sprawie stomii protekcyjnej. Pol Przegl Chir 2014; 86: 717-41. 
4. Didkowska J, Zatoński W. Krajowy Rejestr Nowotworów. Rada Naukowa przy Ministrze Zdrowia Warszawa, 16 March 2011.

5. Borie F, Daures J, Millat B, et al. Influence of environment and healthcare structures on the survival of patients with colorectal cancer: a French population-based study. J Surg Oncol 2002; 80: 137-42.

6. Grzebieniak Z, Szynglarewicz B. Czynniki prognostyczne w raku okrężnicy i odbytnicy. Prz Lek 2004; 61: 43-53.

7. Phillips R, Hittinger R, Blesovsky L, et al. Local recurrence following "curative" surgery for large bowel cancer. The overall picture. Br J Surg 1984; 71: 12-6.

8. McArdle C, Hole D. Outcome following surgery for colorectal cancer: analysis by hospital after adjustment for case-mix and deprivation. Br J Cancer 2002; 86: 331-5.

9. Smith J, King P, Lane R, et al. Evidence of the effect of "specialization" on the management, surgical outcome and survival from colorectal cancer in Wessex. Br J Surg 2003; 90: 583-92.

10. Runkel N, Schlag P, Schwarz V, et al. Outcome after emergency surgery for cancer of the large intestine. Br J Surg 1991; 78: 183-8.

11. Gui J, Wang L. Anastomotic leakage mid-low rectal cancer patients following pre-radiated and total mesorectum excision. Ann Oncol 2008; 19: 24.

12. Cong ZJ, Fu CG, Wang HT, et al. Influencing factors of symptomatic anastomotic leakage after anterior resection of the rectum cancer. World J Surgery 2009; 33: 1292-7.

13. Pata G, D'Hoor A, Fieuws S, Pennickx F. Mortality risk analysis following routine vs. selective defunctioning stoma formation after total mesorectal excision for rectal cancer. Col Dis 2009; 11: 797-805.

14. Cong ZJ, Hu LH, Bian ZQ, et al. Systematic review of anastomotic leakage rate according to an international grading system following anterior resection for rectal cancer. PLoSOne 2013; 8: e75519.

15. Matthiesen P, Hallbook O, Rutegaard J, et al. Defunctioning stoma reduces symptomatic anastomotic leakage after low anterior resection of the rectum for cancer. Ann Surg 2007; 246: 207e14.

16. Wiraszka G, Kielar M, Stępień R. Ocena zagrożenia rakiem jelita grubego w Polsce na podstawie analizy wspó1czynników epidemiologicznych. Studia Medyczne 2015; 31: 66-74.

\section{Address for correspondence:}

\section{Monika Kozłowska}

Faculty of Health Sciences

Jan Kochanowski University

ul. IX Wieków Kielc 19, 25-317 Kielce, Poland

Phone: +48 602390428

E-mail: monikachir@gmail.com 